\title{
Haemodynamic and Humoral Profiles of Indonesian Elderly Hypertensive Patients
}

\author{
Endang Susalit, Radja Pingkir Sidabutar
}

\begin{abstract}
Abstrak
Untuk mengetahui profil hemodinamik dan humoral penderita hipertensi usia lanjut, telah diselidiki 60 penderita hipertensi ( 30 berusia lebih dari 60 tahun dan 30 kurang dari 40 tahun ). Tekanan darah arteri rata-rata, jenis kelamin, tinggi dan berat badan kedua kelompok setara.Curah jantung, indeks jantung, frekwensi denyut jantung, aliran darah ginjal,laju filtrasi glomerulus dan aktifitas renin plasma lebih rendah, sedangkan ukuran tebal septum dan dinding posterior ventrikel kiri, resistensi vaskuler perifer total dan ginjal serta kadar peptida natriuretik atrium plasma lebih tinggi pada penderita hipertensi usia lanjut. Disimpulkan bahwa hipertensi pada usia lanjut merupakan penyakit dengan profil kardiak, hemodinamik dan humoral yang khas.
\end{abstract}

\begin{abstract}
In an attempt to investigate the haemodynamic and humoral profile of the elderly hypertensive patients, 60 patients ( 30 older than 60 years and 30 younger than 40 years) were studied. The elderly patients were matched for mean arterial pressure, sex, height and weight with the younger patients. Cardiac output, cardiac index, heart rate, renal blood flow, glomerular filtration rate and plasma renin activity were significantly lower in the elderly, whereas total peripheral as well as renal vascular resistance, left ventricular posterior wall, septal thickness and plasma atrial natriuretic peptide were higher. It is concluded that hypertension in the elderly is a distinct entity with specific cardiac, haemodynamic and humoral findings.
\end{abstract}

Keywords : Hypertension, elderly, haemodynamic and humoral profile

\section{INTRODUCTION}

In industrialized societies, the prevalence of hypertension in patients of 65 years of age or older is over $50 \%,{ }^{1}$ whereas the present authors found the prevalence of hypertension in Indonesian people over 60 years of age is around $30 \%$. Because the prevalence of elevated blood pressure increases with age ${ }^{2}$ and because the life expectancy of the Indonesian people will be much longer in the coming years, the magnitude of the problem of elderly hypertension in Indonesia is expected to increase.

For many years, the age related rise in blood pressure was considered a normal and inevitable haemodynamic consequence of growing old. This belief caused some authorities to advocate therapeutic nihilism for elderly patients with hypertension. ${ }^{3}$
However, more recent data show that these pressure increases are associated with risks for cardiovascular complications ${ }^{4}$ and its treatment has been shown to be beneficial. ${ }^{5,6}$ National High Blood Pressure Education Program Working Group also had made recommendations that raised blood pressures in the elderly and the increased prevalence of hypertension in this population are not benign occurrences and should not be viewed as a normal or inevitable consequence of aging. ${ }^{7}$ Furthermore, there is increasing interest in the pathophysiology of hypertension in the elderly, because this understanding could lead to better methods of control either through dietary modifications or use of drug therapy.

Some authors have suggested that clinical and pathophysiological findings of essential hypertension in the elderly are different from that of the younger, ${ }^{8}$ 
but only a few data is available to support this concept. ${ }^{9}$ Thus, in an attempt to provide additional data, we investigated the haemodynamic and humoral parameters in the elderly hypertensive patients and compared them with younger adults. We matched elderly patients for mean arterial pressure, sex and body height and weight with corresponding younger subjects and compared their haemodynamic and humoral profiles.

\section{MATERIALS AND METHODS}

We investigated 60 essential hypertensive patients (30 older than 60 years and 30 younger than 40 years). The matching procedure took into account mean arterial pressure, weight, height and age. Patients with essential diastolic and isolated systolic hypertension were included in this study. Some patients had never been treated for high blood pressure, and in all others antihypertensive therapy was discontinued at least 2 weeks before the study. The patients were informed of the nature and purpose of the study and were asked to give their consent to participate. Patients with malignant or accelerated hypertension, and/or any other severe concomitant pathologic condition were excluded.

Haemodynamic and echocardiographic assessments were carried out by measurement according to a standard method ${ }^{10}$ using M-mode echocardiogram. Total peripheral resistance was calculated as the ratio of mean arterial pressure to cardiac output. Effective renal plasma flow was determined by a single injection of ${ }^{131}$ Iodine-labelled para-aminohippuric acid, whereas glomerular filtration rate was measured by a single injection of ${ }^{99 \mathrm{~m}}$ Technetium-labelled diethylenetriaminepentaacetic acid. Renal blood flow was calculated by dividing effective renal plasma flow by the term ( 1 - hematocrit). Renal vascular resistance was derived from the ratio of mean arterial pressure to renal blood flow.

Plasma renin activity was measured after 30 minutes of sitting by radioimmunoassay methods using commercial kit (Angiotensin I-Biotecx Radioimmunoassay Kit). Circulating level of insulin was determined from venous blood after an overnight fast by radioimmunoassay kit(Coat-A-Count Insulin).The radioimmunoassay methods were also used to assess plasma concentration of atrial natriuretic peptide (HANP Kit Eiken) and the amount of catecholamine in 24-hour urine output (Amicyl-Test Katcombi).

A two-tailed $t$ test was used to compare the elderly and younger hypertensive patients, and statis- tical significance was calculated at $5 \%$ level. Data are presented as the mean SD.

\section{RESULTS}

Table 1. Clinical findings

\begin{tabular}{|c|c|c|}
\hline & Elderly & Young \\
\hline Age $(y r)$ & $61.8 \pm 7.1$ & $31.7 \pm 5.8$ \\
\hline $\mathrm{M} / \mathrm{F}$ & $17 / 13$ & $19 / 11$ \\
\hline Height (m) & $1.60 \pm 0.09$ & $1.65 \pm 0.12$ \\
\hline Weight(kg) & $63.4 \pm 10$ & 65.214 \\
\hline Body surface area $(\mathbf{m} 2)$ & $1.66 \pm 0.15$ & $1.70 \pm 0.19$ \\
\hline Systolic pressure $(\mathrm{mmHg})$ * & $175 \pm 28.2$ & $152 \pm 23.7$ \\
\hline $\begin{array}{l}\text { Mean arterial pressure } \\
\quad(\mathrm{mmHg})\end{array}$ & $110 \pm 17.2$ & $109 \pm 18.1$ \\
\hline Diastolic pressure $(\mathrm{mmHg})$ * & $80.8 \pm 11.8$ & $91.6 \pm 11.4$ \\
\hline Heart rate(beass/min) * & $68.2 \pm 9.3$ & $73.4 \pm 9.8$ \\
\hline
\end{tabular}

* $p$ value $<0.05$

The data from clinical findings showed that elderly patients were on average around 30 years older than the younger subjects.

Other features such as sex, body height,weight and surface area were similar in both patient groups, because of the matching procedure. Mean arterial pressure was held equal by the design of the study. Systolic pressure was higher, but diastolic pressure and heart rate were lower in the elderly than those of the younger patients (Table 1).

Cardiac output, cardiac index, and stroke volume were significantly lower in the elderly patients than in the younger group.

Echocardiographic data showed that the left ventricular wall and septum were thicker in elderly patients.

Table 2. Haemodynamic and echocardiographic lindings

\begin{tabular}{|c|c|c|}
\hline & Elderly & Young \\
\hline Cardiac output $(1 / \mathrm{min})$ * & $4.51 \pm 1.17$ & $6.03 \pm 1.29$ \\
\hline Cardiac index $(1 / \mathrm{min} / \mathrm{m} 2)$ * & $2.59 \pm 0.51$ & $3.29 \pm 0.54$ \\
\hline Slroke volume $(\mathrm{ml})$ * & $67.8 \pm 17.4$ & $83.8 \pm 19.7$ \\
\hline LV wall thickness $(\mathrm{mm})$ * & $11.8 \pm 1.3$ & $9.3 \pm 2.0$ \\
\hline IV sepla! thickness (mm) * & $10.9 \pm 3.3$ & $9.5 \pm 3.1$ \\
\hline $\begin{array}{l}\text { Total peripheral resistance * } \\
\text { (units) }\end{array}$ & $24.9 \pm 7.4$ & $18.1 \pm 5.5$ \\
\hline Renal blood flow $(\mathrm{m} l / \mathrm{min})$ * & $650 \pm 89$ & $1057 \pm 247$ \\
\hline $\begin{array}{l}\text { Renal vascular resistance * } \\
\text { (units) }\end{array}$ & $170 \pm 18$ & $107 \pm 15$ \\
\hline $\begin{array}{l}\text { Glomerular filltration rate * } \\
(\mathrm{ml} / \mathrm{min} / 1.73 \mathrm{~m} 2)\end{array}$ & $87 \pm 20$ & $119 \pm 18$ \\
\hline
\end{tabular}

* $\mathrm{p}$ value $<0.05$ 
Total peripheral and renal vascular resistance were higher in the elderly, and renal blood flow and glomerular filtration rate were lower when compared to those of the younger group ( Table 2).

Table 3. Humoral findings

\begin{tabular}{lcc}
\hline & Elderly & Young \\
\hline $\begin{array}{l}\text { Plasma renin actvily * } \\
(\mathrm{ng} / \mathrm{m} / \mathrm{h})\end{array}$ & $0.98 \pm 0,62$ & $1.53 \pm 0.91$ \\
$\begin{array}{l}\text { Insulin } \\
(\mathrm{mU} / \mathrm{L})\end{array}$ & $20.8 \pm 7.2$ & $21.7 \pm 12.4$ \\
$\begin{array}{c}\text { Alrial natriuretic peptide * } \\
(\mathrm{pg} / \mathrm{ml})\end{array}$ & $53.3 \pm 21.4$ & $38.5 \pm 17.2$ \\
$\begin{array}{l}\text { Catecholamine } \\
(\mathrm{nmol} / 24 \mathrm{~h})\end{array}$ & $161 \pm 28$ & $156 \pm 27$ \\
\hline
\end{tabular}

${ }^{\star}$ p value $<0.05$

Plasma renin activity was significantly lower in the elderly, and 24-hour urine catecholamine was slightly but not significantly higher.

No difference was observed in plasma insulin level, but plasma atrial natriuretic peptide was significantly higher in the elderly (Table 3 ).

\section{DISCUSSION}

With advancing years, several changes occur in the anatomy and physiology of the cardiovascular system. These changes involve both the heart and the systemic vasculature. The major problem in studying the effects of age and hypertension on the cardiovascular system, has been to distinguish age-related from hypertensionrelated changes in structure and function. Several reviewers believe that elderly hypertensives represent a unique and growing subset that deserves special consideration.., 11

The results of this study suggests that the pathophysiological features of essential hypertension in the elderly differ distinctly from those in the younger patients. In the elderly, essential hypertension is characterised by a hypertrophied heart, asscociated with a low systemic and renal blood flow, working against a high total peripheral resistance. Indeed, the thicker left ventricular wall and septum were found in the elderly group.

The low cardiac output results from both a smaller stroke volume and a reduced heart rate. When cardiac output declines and mean arterial pressure remains unchanged or rises, total peripheral resistance can be expected to rise. Several small prospective studies have shown that early in the course of hypertension there is a hyperkinetic circulation, during which peripheral resistance is normal and cardiac index is increased. As hypertension progresses, peripheral resistance gradually increases and cardiac index falls. ${ }^{12}$

Effects of age on renal haemodynamics have also been studied. ${ }^{13,14}$ All have shown an age-related decline in renal blood flow and glomerular filtration rate. The decline in renal blood flow in our elderly hypertensive patients is not a secondary phenomenon related to the fall in cardiac output. In this study, renal blood flow was $39 \%$ lower in the elderly patients, whereas the fall in cardiac output was only $25 \%$, indicating a redistribution of cardiac output in the elderly, probably resulting from nephrosclerosis, as suggested by the increased renal vascular resistance.

Schmieder et al, reported that patients with established hypertension have an accelerated decline in renal perfusion with aging, reflecting selective functional or structural changes or both in renal vascular bed ${ }^{15}$

The renin-angiotensin-aldosterone system plays a key role in salt and water homeostasis and in the regulation of vascular tone. ${ }^{16,17}$ It is well established that renin is inversely correlated with age. ${ }^{18}$ This study supports other reports which demonstrated a lower plasma renin activity in elderly than in younger patients. ${ }^{9,19}$

Imbalances in several neurotransmitters and neuromodulators are present during the development of hypertension and these may contribute to increased release of norepinephrine onto the postsynaptic targets of the sympathetic nerves. ${ }^{20}$

Esler et al showed that reduced norepinephrine reuptake increases the overflow of the neurotransmitter to plasma from the aging heart during stimulation of the cardiac sympathetic out -flow. ${ }^{21}$ In elderly subjects, baseline sympathetic nerve activity per se seems to be increased, as shown by elevated levels of circulating catecholamines and by a higher level of muscle sympathetic nerve activity recorded by microneurography. ${ }^{22}$ Thus, the elevation of plasma norepinephrine and exagerated responses to stimuli in the elderly could play a role in hypertension.

In this study the increase of 24-hour urine catecholamine was not significant. This result is in accord with the study of Goldstein et al, which suggested that the age-effect on plasma norepinephrine levels was obscured in hypertensive patients, because of elevated value in those of younger than in the elderly subjects. $^{23}$

The current interest concerns linking hypertension to hyperinsulinemia and insulin resistance through increased vascular resistance. Both animal 
and human data support the idea that insulin resistance is associated with enhanced pressor responsiveness. ${ }^{24}$ Further supports come from Grunfeld et al who found the time precedence of hyperinsulinemia and possibly insulin resistance over the appearance of clinical hypertension in a high-risk population. ${ }^{25}$ Although we observed higher total peripheral resistance in the elderly than in the younger subjects, there was however no difference in fasting plasma insulin level in both groups.

Fasting plasma insulin and glucose disposal during a hyperinsulinemic euglycemic clamp may provide different estimates of insulin resistance. Fasting hyperinsulinemia may reflect mainly hepatic insulin resistance, whereas impairment of glucose disposal indicates resistance to the metabolic effects of insulin in skeletal muscle. ${ }^{26}$ Dengel et al using the three-dose hyperinsulinemic euglycemic clamp concluded that hypertensive obese, sedentary older men have a reduction in both sensitivity and maximal responsiveness to insulin which is directly related to the severity of hypertension, independent of obesity and physical fitness. 27

Atrial natriuretic peptide was sequenced 10 years ago. ${ }^{28}$ Berglund et al ${ }^{29}$ and Joshimura et al. ${ }^{30}$ showed good evidences that atrial pressure determines atrial natriuretic peptide concentrations, whereas Parkes et al reported that the increase in atrial natriuretic peptide is gradual and may be dependent on the gradual increase in right atrial pressure. ${ }^{31}$

The accumulated evidence indicates that atrial natriuretic peptide is implicated in the control of blood pressure, body fluid homeostasis, and vascular remodelling as both cardiac hormone and local regulator. ${ }^{32}$ Thus, atrial natriuretic peptide due to its renal, endocrine and cardiovascular actions, may have a physiological role in the elderly hypertensive patients. In this study, we found that plasma atrial natriuretic peptide was significantly higher in the elderly as reported by others. ${ }^{33}$ Taken together, all of the studies suggest that an age-related increase in plasma atrial natriuretic peptide may be present.

\section{CONCLUSIONS}

Hypertension in the elderly is a distinct entity with specific cardiac, haemodynamic, and humoral findings.

\section{Acknowledgements}

The authors wish to thank the P.T. Tanabe Abadi Jakarta, Indonesia for the sponsorship.

\section{REFERENCES}

1. Busse JC, Matterson BJ. Geriatric hypertension : the growing use of calcium-channel blockers. Geriatrics 1988; 43: 51-8.

2. Tell GS, Rutan GH, Kronmal RA et al.Correlates of blood pressure in community-dwelling older adults. The cardiovascular health study. Hypertension 1994;23:59-67.

3. Flack JM, McVeigh G, Grimmy RH. Hypertension therapy in the elderly. Curr Opin Nephrol Hypertens 1993;2:386-94.

4. Ostfeld AM, Shekelle RB, Klawans H, Tufo HM. Epidemiology of stroke in an elderly welfare population . Am J Public Health 1974;64:450-8.

5. Pearce KA, Furberg CD. Hypertensive cardiovascular disease and the treatment of hypertension in the elderly . Curr Opin Nephrol Hypertens 1994;3:213-7.

6. Freis ED. Prognosis in elderly hypertensive patients.Medical Progress 1995;22:14-8.

7. National High Blood Pressure Education Program Working Group.National high blood pressure education program working group report on hypertension in the elderly. $\mathrm{Hy}$ pertension 1994;23:275-85.

8. O`Malley K, O’Brien E. Management of hypertension in the elderly. N Engl J Med 1980;302:1397-401.

9. Messerli FH, Sundgaard-Ruse K, Ventura HO et al.Essential hypertension in the elderly: haemodynamics, intravascular volume, plasma renin activity, and circulating catecholamine levels. Lancet 1983;2:983-5.

10. O'Rourke RA, Hanrath P,Henry WN et al.Report of the Joint International Society and Federation of Cardiology / World Health Organization Task Force on recommendation for standardization of measurements from M-mode echocardiograms. Circulation 1984;69:854A-7A.

11. Kirkendall WM, Hammond JJ. Hypertension in the elderly. Arch Intern Med 1980;140:1155-61.

12. Post WS, Larson MG, Levy D. Hemodynamic predictors of incident hypertension. Hypertension 1994;24:585-90.

13. Papper S. The effects of age in reducing renal function. Geriatrics 1973;28:83-7.

14. Hollenberg NK,Adams DF, Solomon HS, et al.Senescence and the renal vasculature in normal man. Circ Res 1974 34:309-16.

15. Schmieder RE, Schachinger H, Messerli FH. Accelerated decline in renal perfusion with aging in essential hypertension. Hypertension 1994;23:351-7.

16. Laragh JH. The renin system and four lines of hypertension research. Hypertension 1992;20:267-79.

17. Kruse HJ, Kreutz R, Staib $S$ et al. Dissociation of renin and aldosterone during low-dose epinephrine infusion. Am J Hypertens 1994;7:913-8.

18. Ho GYF, Blaufox MD, Smoller SW et al. Plasma renin predicts success of antihypertensive drug withdrawal . Am J Hypertens 1994;7:679-84.

19. Swales JD. Low renin hypertension: nephrosclerosis?. Lancet 1975;i:75-7.

20. Wyss JM. The role of the sympathetic nervous system in hypertension. Curr Opin Nephrol Hypertens 1993;2:265-73.

21. Esler MD, Thompson JM, Kaye DM et al.Effects of aging on the responsiveness of the human cardiac sympathetic nerves to stressors. Circulation 1995;91:351-8. 
22. Veerman DP, Imholz BPM, Wieling W et al. Effects of aging on blood pressure variability in resting conditions. Hypertension 1994;24:120-30.

23. Goldstein DS, Lake CR, Chemow B. Age-dependence of hypertensives-normotensives differences in plasma norepinephrine. Hypertension 1983;5:100-4.

24. Baron AD. Pathogenesis and measurement of insulin resistance in hypertension. Curr Opin Nephrol Hypertens 1994; 3:631-5.

25. Grunfeld B, Balzareti M, Romo M et al . Hyperinsulinemia in normotensive offspring of hypertensive parents. Hypertension 1994;23(Suppl I):I 12-5.

26. Hall JE, Summers RL, Brands MW et al. Resistance to metabolic action of insulin and its role in hypertension. Am J Hypertens 1994;7:772-88.

27. Dengel DR, Pratley RE, Hagberg JM et al.Impaired insulin sensitivity and maximal responsiveness in older hypertensive men. Hypertension 1994;23:320-4.

28. Struthers AD. Effect of ACE inhibitors on the atrial natriuretic peptides in heart failure. Br Heart J 1994;72:504.
29. Berglund H, Nyquist O, Beermann B et al. Influence of angiotensin converting enzyme inhibition on the atrial natriuretic peptide atrial pressure relationship in heart failure.Br Heart J 1994;72:521-7.

30. Yoshimura $M$, Yasue $H$, Tanaka $H$ et al. Responses of plasma levels of A-type natriuretic peptide and B-type natriuretic peptide to alacepril an angiotensin-converting enzyme inhibitor in patients with congestive heart failure. Br Heart J 1994;72:528-33.

31. Parkes DG, Coghlan JP, Cooper EA et al. Cardiovascular action of atrial natriuretic factor in sheep with cardiac failure. Am J Hypertens 1994;7:905-12.

32. Nakao K, Itoh H, Suga S et al. The natriuretic peptide family. Curr Opin Nephrol Hypertens 1993;2:45-50.

33. McKnight JA, Roberts G, Sheridan B, et al.Relationship between basal and sodium - stimulated plasma atrial natriuretic factor, age, sex, and blood pressure in normal man. J Hum Hypertens 1989;3:157-63. 